equipped mobile clinical units is suggested for increased efficiency. It was pointed out at the meeting that no financial assistance is provided, and the burdens now borne by local authorities are such that without assistance from the national exchequer little can be done. Further, it is felt that the Ministry's circular pays insufficient attention to the enlightenment of the public as a preventive measure and makes no mention of the needed increase in the number of trained venereal disease almoners. The omission of any reference as to the means whereby local authorities are to be financially re-imbursed for providing these services has caused considerable dissatisfaction. A strongly worded resolution to that effect was adopted.

\section{Development of International Health Organizations}

IN a recent paper (Ann. Med. Hist., 3 ser., 1, 519; 1939), Dr. Robert A. Lyon, of Cincinnati, points out that before the nineteenth century individual nations or cities tried to check the entrance of disease by the application of quarantine laws at ports and land frontiers. It was not, however, until the early decades of the nineteenth century that international co-operation in health matters was first sought by countries on the Mediterranean. In 1839, Turkey invited representatives of other nations to meet a Sanitary Commission at Constantinople for better cooperation in the enforcement of quarantine regulations. A few years later, Egypt made a similar request, and in 1869 the Egyptian Council at Alexandria undertook the medical supervision of traffic through the Suez Canal. In 1851 the first International Health Convention met in Paris, and since then thirteen similar conventions have been held in different European cities and at Washington for the purpose of formulating regulations concerning the notification of cholera and plague and arrangement of medical inspection of crews and passengers as well as the inspection and disinfection of cargoes.

In 1909 there was established in Paris an International Hygiene Office, the function of which has been to collect and unify the many national laws of sanitation and quarantine, to supervise the health laws applicable to pilgrims, to establish medical facilities for the treatment of venereal disease in ports in all parts of the world, to investigate the transmission of disease by aerial navigation, to publish public health information, and to carry out specific investigations. The organization of a Health Section of the League of Nations began in 1920, and in 1921 it became part of the permanent secretariat of the League, with offices in Geneva. The Section consists of three divisions, namely, a directing committee, a consulting committee of experts consisting of the directors of the International Health Office, and an executive staff composed of public health experts, statisticians and clerks who devote their whole time to the work. The Section has done valuable work in the control of epidemics, the standardization of medical procedures, and the collection and publication of medical information.

\section{Black-Headed Gull Survey}

THE survey of the black-headed gull (Larus ribibundus) carried out by P.D. Hollom, with the help of 160 other observers for the British Trust for Ornithology (British Birds, Jan. 1939), gives a total number of 70,000 breeding pairs in 124 gulleries in England in 1938 and 6,000 in 34 gulleries in Wales. There were 145 gulleries in Scotland and 39 in Ireland; but it is believed that more birds exist in these two countries, which were not fully surveyed. The larger part of the gull population is in the north of Britain, and although there has been a great increase at many places this century, there were probably larger numbers of gulls in the country a century ago, and at many northern gulleries there has been a decline in recent years. The largest British gullery, at Ravenglass, Cumberland, has 50,000 birds-five times that of the next largest and two thirds of the total gull population of England. There are no gulleries of this species in the Isle of Man, and strikingly few in the counties bordering the Bristol Channel.

Nearly forty per cent of the colonies are twenty miles or more inland from the sea and the highest at 1,925 ft. above sea-level at Greensett Moss, Great Whernside, Yorkshire, formed in 1921, where 200 pairs nested in 1938. The total number of colonies in the British Isles is given as 488 , but there is also a very lengthy list of deserted colonies. Some of the gulleries, as the Delamere Forest of Cheshire, date back to the early seventeenth century. There seems to be no truth in the belief that use of these eggs for food during the War of 1914-18 depleted many of the present gulleries and tended to disperse the gulls over a wider area, as this started before 1914 in many instances. Cumberland and Yorkshire are very rich in these gulleries, the former county having 19, many of them on the Solway marshes, and the latter county having 29 .

\section{Marriage-Rate in War-time}

Tнш November issue of the Statistical Bulletin of the Metropolitan Life Insurance Company of New York contains a review of the course of the marriagerate during the War of 1914-18 in the countries immediately concerned. With the outbreak of hostilities in 1914 the marriage-rate of all the belligerent countries fell precipitously. In France, for example, the rate dropped from a level of about 8 per 1,000 during the period $1851-1913$ to a minimum of $2 \cdot 3$ in 1915 . In Germany the pre-war average rate of about 8 per 1,000 sank to $4 \cdot 1$ in 1915 and 1916 . In Italy the rate fell to $2 \cdot 7$ in 1917 . In England and Wales the rate, which for a long time had been about 8 per 1,000 , showed a transient rise to $9 \cdot 7$ in 1915 and then fell to 6.9 in 1917. In the United States the minimum reached in 1918 was not far below an average of 10.4 for 1914-16, the years preceding the entrance of the United States into the war. The end of the War was followed by a prompt rebound to unusually high figures. Thus in France the rate rose from 5.5 per 1,000 in 1918 to 14.0 in 1919 and $16 \cdot 0$ in 1920, and similar though less 
pronounced rises took place in Germany and most of the other belligerent countries. Even some of the neutral countries showed a distinct reaction, which in the case of Switzerland was more marked than that of England and Wales.

\section{Rehabilitation of Adult Prostitutes}

Experience shows that the problem of prostitution tends to acquire particular importance in time of war, not only for the countries directly involved but also for other countries, and the publication by the League of Nations Secretariat of a third and concluding volume of studies on this subject is therefore opportune (League of Nations Pamphlet, iv, 4, Messrs. Allen and Unwin, 40 Museum Street, London, W.C.1 ; 1939. 3s. 6d. net). An endeavour is made in this volume to elucidate the controversial question of possibilities of reclaiming prostitutes for re-entry into the normal life of the community. Institutional training is discussed at some length, and an account is given of the different approaches made by various types of institutions, religious and lay, to the problem. The Advisory Committee which studied this question came to the conclusion that, if certain principles are applied and certain psychological factors recognized, rehabilitation of adult prostitutes is, within limits, both feasible and successful. The volume should be useful not only to those directly concerned with the problem of rehabilitation, but also to all social workers who have to deal with the very complex question of prostitution in general.

\section{London School of Hygiene and Tropical Medicine}

The report for 1938-39 of the London School of Hygiene and Tropical Medicine, incorporating the Ross Institute, is, as usual, of great interest. It should be realized that studies which seem minute and insignificant, such as the survival and fertility of insects under highly unfavourable conditions, may be of the utmost importance to planters and owners of big estates. They should subscribe more generously to a School which does so much for their welfare. The Institute, while busy at home with many discoveries, including bacterial survival for well over a century, has been continuing the attack on the problems of Anopheles minimus in Assam, a mosquito which can be controlled more effectively by shading than by the use of drugs.

It is very satisfactory to learn that in the chief field stations of tea estates in India it has been possible to train a staff of Indians as surveyors of malaria and laboratory assistants. The annual malaria control course for laymen which started at the Institute in 1929 is free, and from small beginnings has now attracted more than a thousand learners. Ceylon has had in the past great outbreaks of malaria due to drought, but the failure of two monsoons during the year under survey did not lead to the major outbreak that might have been expected. The Ceylon Government and the Estates Malaria Control scheme confined the trouble to minor eruptions. This is a specimen of the remarkable work that is done.
The energies of the Institute are, indeed, far flung. They have been extended to the Gold Coast and the question of mass emigration of refugees from Central Europe to British Guiana. Dr. Chester Beatty's speech at the annual 'Mosquito Day' luncheon dwelt rightly on the comparatively meagre support given. Some of the travelling specialists are constantly employed and clearly overworked.

\section{A New Type of Wood-Burning Stove}

A NEW stove, developed by the Connecticut Forest and Park Association in co-operation with Prof. L. E. Seeley, heating expert of Yale University, burns wood with an efficiency estimated at ninety per cent. It is capable of heating two or three rooms and requires filling only once or twice a day. A report issued by Science Service, of Washington, D.C., says that the new heater holds about two and a quarter cubic feet of wood, or slightly more than $50 \mathrm{lb}$. It is estimated that it will generate about 40,000 B.T.U./hr. for an eight-hour period without attention. This amount of heat is sufficient for two or three rooms in cold weather. In mild weather the heater will easily run more than twenty-four hours without attention.

The new heater differs radically in design from the usual type of wood-burning stove. Air supply is limited as in any tight heater, but all air is not directed into one space, as is customary; instead, provision is made for pre-determined amounts of air to enter the combustion chamber, while a separate air supply is allowed to mix with the highly heated gases formed by the burning wood. The wood gases are passed through small passage-ways called combustion ports where they are burned separately from the wood. The process is a partial distillation of the wood producing charcoal and gas, and the products are burned in different spaces. The result is high efficiency with a minimum of loss in soot, creosote and ash. The Governor of Connecticut, who has expressed interest in the establishment of a permanent outlet for the firewood now being wasted in the State for lack of a market, has made possible a small-scale commercial experiment in the use of wood as fuel in State institutions.

\section{Electrical Thawing}

DURING the recent cold spell, serious inconvenience has been caused in many households by the freezing of water services. In the Electrical Review of February 2, a letter from Mr. C. W. Salt, the city electrical engineer to Carlisle, is published describing an effective and 'easily applied method of thawing frozen water services, when a public A.C. supply is available. In Carlisle, where the voltage is 230 , a double-wound single-phase transformer is used, the ratio being $230 / 12$, with a regulating resistance on the primary side and an ammeter scaled $0-250$ on the secondary side. The primary is plugged into a 15 amp. radiator socket and the secondary leads are attached to a tap or pipe inside the house and to the stopcock of a neighbouring house. The regulating resistance is adjusted until the secondary current flows through 